\title{
ALCANCE Y LÍMITES DE LA EDUCACIÓN
}

\author{
Pilar PALOP JONQUERES*
}

\section{INTRODUCCIÓN}

\section{La educación como esperanza}

Examinar el alcance y límites de la actividad educativa es, sin duda, uno dedos asuntos más importantes de la Filosofía de la educación, pues constituye una cuestión propedéutica que se halla en el núcleo mismo de la crítica de la razón pedagógica.

Es evidente, sin embargo, que se trata de un problema a menudo olvidado. Acaso porque los educadores necesitan una gran dosis de optimismo pedagógico para acometer sus trabajos con el entusiasmo preciso, acaso porque nuestro siglo deposita en la práctica docente grandes esperanzas, el hecho es que raramente la teoría educativa se detiene a examinar el alcance $y$, por tanto, los límites de la educación.

No ocurre lo mismo cuando se examinan las facultades cognoscitivas. La tradición filosófica ha sabido habituarse a ese cuestionamiento incesante, emprendido por Locke y Hume y codificado por Kant, en torno a las condiciones de posibilidad del conocimiento humano. No resulta, pues, difícil, reconocer que las capacidades cognoscitivas del hombre poseen determinaciones imposibles de trasgredir, que les vienen dadas por los marcos de nuestra sensibilidad, por la estructura del entendimiento y por la "fisiologías de nuestra razón.

Mucho menos sencillo tesulta, sin embar. go, admitir límites a la acción humana. Se diría que, en lo que se refiere a la "praxis", existe una creencia extendida en cuanto a sus infinitas posibilidades para transformar el mundo cultural y social.

El propio Kant y la filosofía moral postkantiana son responsables, en gran medida, de esa creencia optimista. Adviértase, en este sentido, que el filósofo de Könisberg orientó su Crítica de la Razón Práctica en una dirección distinta a la que había dado a la Crítica

* Nacida en 1947. Desde 1970 es profesora de Filosofía (Sección Pedagogía) en la Universidad de Oviedo. Su obra más relevante es Epistemología genética y Filosofia (Barce. lona. Arjel, 1981). Asimismo ha colaborado en el Dicciona. rio de Filosofia contemporánea, editado por Quintanilla (Salamanca, Editorial Sigueme, 1976). de la Razón Pura. Y así, mientras que, frente a la razón especulativa, Kant trató de dar res" puesta a la pregunta: "¿qué "puedo" saber?", ante la razón práctica no se preguntó acerca del "poder», sino del "deber». De este modo, concibió su Crítica de la Razb́n Práctica como la respuesta escolástica y acadérnica a la pregunta cósmica y mundana de "¿qué "debo" hacer?", pero no a la pregunta: "¿qué "puedo" hacer?".

Es más, como tantas veces se ha dicho, Kant fue el gran adalid de la libertad, el filósofo que supo reinstaurar, sobre bases nuevas y más potentes que nunca, la confianza en el libre albedrío; una confianza que se había tambaleado en el s. XVII, a causa del ocasionalismo, del providencialismo leibniziano o del spinozismo; pero que había llegado a peligrar, sobre todo, en el propio s. XVIII, en el cual el materialismo mecani* cista propendía a extender, también al hombre, la doctrina cartesiana del mecanismo de las bestias o, en sus posiciones menos radicales, a interpretar la vida moral como resultado de fuerzas pasionales cuya composición se pensaba, en gran medida, análoga a la de las fuerzas mecánicas.

Ante la razón pura, Kant no negó, sino que reconoció, la antinomia entre el deter. minismo y la libertad. Pero en el ámbito de la razón práctica, postuló la libertad como una intuición originaria, como un hecho de la experiencia interna tan irreductible y primario como los datos espacio-temporales con respecto a la experiencia exterior. Erigió, así como es sabido, la evidencia del libre albedrío en piedra de toque y condición misma de posibilidad del juicio moral, de modo análogo a como había fundamentado la validez de los juicios del entendimiento en las intuiciones espacio-temporales.

Pues bien, al hacer de la libertad la «ley apodíctica de la razón práctica", Kant legó a la filosofía posterior una fe inamovible en las posibilidaơes de la acción humana. Tal fue la importante herencia que dejó a Fichte o a Hegel, quienes, como Kant, concibieron la Historia orientada a la construcción de la libertad.

Pese a sus críticas contra el formalismo y el intelectualismo de la moral kantiana, y 
aun reconociendo la potencia inconsciente de la voluntad, de las pasiones o del deseo (incluso, como el marxismo, subrayando las determinaciones materiales y sociales de la conciencia), la filosofía postkantiana seguirá confiando en la capacidad de la praxis para transformar el mundo.

Ciertamente, esta filosofía admitirá que la conciencia es engañosa, que necesariamente yerra, y pondrá de manifiesto que los errores proceden, con frecuencia, de las astucias dei deseo o de los intereses materiales que envuelven la existencia. Irá, en este sentido, más lejos que el propio Kant, por el camino abierto en la Dialéctica Transcendental.

Sin embargo, la Teoría de la Falsa Conciencia no obtendrá del autoengaño de la razón conclusiones que hayan podido ir en detrimento del postulado de la libertad. Porque, indudablemente, cabría haber concluido que la ilusión transcendental y, con ella, las ideologías o el inconsciente, constituáan, no ya sólo obstáculos para el recto conocimiento, sino cortapisas para la responsabilidad, en la "praxis». Pero, en general, no ha ocurrido así. Más bien la conciencia que se engaña, la conciencia interesada, ha tendido a ser considerada, de un modo u otro, como culpable de su error. Sartre la conceptuará expresamente como producto de la umala fe").

Así pues, a partir de Kant, las más importantes corrientes filosóficas -incluyendo al vitalismo, al marxismo o al existencialismo-han sidofilosofías de la libertad. Ni siquiera el estructuralismo ha logrado quebrar seriamente el axioma del libre albedrío.

También la filosofía mundana, y no sólo la académica, es todavía, de modo preponderante, una filosofía de la libertad. Resulta muy difícil hacer pensar a los pueblos, a las colectividades, a los individuos, que la acción transformadora y creadora del hombre no puede remover cualquier obstáculo para mejorar las formas de vida, y revolucionar a su guisa - si no se opusiera a ello ia voluntad de los poderosos o la astucia de las clases dominantes- el mundo social. La creencia en las posibilidades infinitas de la acción humana, así como en la perfectibilidad indefinida de las condiciones de existencia, cons- tituyen aún, claramente, los axiomas de la filosofía social de nuestra época.

Sin duda van haciéndose cada día más evi. dentes los límites del desarrollo tecnológico y científico. Con ello, la creencia en un progreso indefinido va siendo puesta en cuestión de modo paulatino. Pero las razones de la duda son de naturaleza económica o ecológica, es decir, referidas a circunstancias exteriores a la acción, no a la acción humana en sí misma. Se piensa, en efecto, que los límites de un progreso indefinido vienen dados exclusivamente por el hecho de que el espacio vital del hombre - la Tierra y sus tecursos-son finitos, pero siempre en la convicción de que, si esa restricción no se diera, nada podría frenar la infinitud creado. ra y absolutamente libre de la voluntad humana.

Pues bien, la actividad educativa es una determinación particular de la razón práctica, aquejada, como aquélla, del mismo optimismo de la libertad. En efecto: en la educación y en el influjo de las escuelas y de los educadores, los pueblos y las colectividades tienen puestas muchas esperanzas de cambio social. De la igualdad de oportunidades en educación esperan una nueva forma de justicia distributiva. De la educación ecológica de los niños esperan obtener transformaciones importantes en la conducta del hombre futuro frente a la naturaleza y sus recursos. De la educación cívico-social esperan obtener futuros ciudadanos, amantes de la democracia y de sus libertades formales, que hagan posible la recurrencia de estos sistemas políticos. $Y$, en fin, del mejoramiento indefinido de la docencia esperan obtener una humanidad mejor y un futuro mejor para la humanidad.

Por tanto, con respecto al alcance de la educación, prevalece, en general, esa misma consideración optimista que todo lo espera de la perfectibilidad de la praxis humana y de sus productos.

El optimismo acerca de las virtualidades de la educación para resolver los problemas del futuro se mantiene, a pesar de los numerosos motivos que habría para desconfiar de su eficacia. Porque, como afirma Bernfeld (3, p. 40): 
... la pedagogía no cumple con lo que es" peramos de ella, no proporciona indicaciones claras, inequívocas, concretas; los medios de que se sirve raramente tienen efec. to seguro; sus pronósticos son frecuentemente falsos (...) y siempre tales que remi* ten a un futuro remoto e imprevisible. Si en estas condiciones no se manifiesta una rápida disminución del interés, se debe sobre todo al hecho de que cada interesado que, por desilusión o porque sus hijos ya supe. raron los años críticos, vuelve las espaldas a la pedagogía, es reemplazado por un nuevo interesado que se encuentra en la nueva situación de padre.

La fe a ultranza en las potencialidades de la educación pudiera responder a una idea verdadera, pero también pudiera ser el efecto de una ilusión. De momento, sin embar. go, solamente algunas voces, de resonancias, a menudo, apocalípticas, como las de Illich - Reimer, se alzan incrédulas ante lo que consideran el "mito del progreso indefinido de la educación» (Cfr. 38, pp. 66-67). Sus argumentos para dudar de ese progreso son, sobre todo, de naturaleza económico-política.

La cuestión del alcance y límites de la educación necesita, sin embargo, ser contemplada por la filosofía, pues pudiera ocurrir que dichos límites no fueran puramente externos, de naturaleza económica, sino que vinieran dados por razones internas de la pedagogía misma.

\section{Las grandes ideas pedagógicas}

Difícilmente podremos hablar del alcance y límites de la educación si no conocemos primero sus aspiraciones. ¿Qué metas, qué fines se propone realizar la educación y hasta qué punto puede acometer y llevar a cabo sus propósitos? Éstos nos vienen dados siempre, a lo largo de la historia del pensamiento pedagógico, por mediación de grandes ideas que, en cuanto tales, tienen aquel formato desentrañado por Kant en la Dialéctica Transcendental.

En efecto, las ideas pedagógicas, como producto y contenido característico de la
Filosofía de la Educación, son siempre construcciones ideales, paradigmáticas que, al modo de prototipos, orientan la conducta y presiden la actividad educativa. Ninguna práctica singular coincide exactamente con ellas, porque no son fruto de la experiencia, sino de la razón pedagógica pura cuando, entregada a su libertad, abandona el país de los fenómenos, que le arropa en la evidencia de lo que hay, y se adentra en el mar de la ilusión. Allí se aventura entre nieblas que le engañan, con la promesa de nuevas tierras y descubrimientos, con el señuelo de una perfección inalcanzable, cuya prosecución no puede abandonar.

Platón había concebido las ideas como causas originarias de las cosas. Kant sabrá entender que esta causación se produce sólo ante la voluntad, la cual, en virtud de su autonomía, "produce objetos correspondientes a las representaciones o por lo menos se determina a sí misma para lograrlas" (21, p. 18).

En todo caso, las ideas tampoco son enteramente ajenas a las realidades de la experiencia. Proceden siempre de ella, aun cuando la desbordan, escapan del territorio del entendimiento y se extravían en los espejismos de la razón. Y ello porque la experiencia es siempre parcial, particular. Pero la razón necesita inevitablemente sobrepasar los límites restringidos de la experiencia, porque es razón constructiva y creadora. $\mathrm{Su}$ operación genuina es la producción de ideas absolutas, que totalizan las condiciones de toda experiencia posible y que, precisamente por ser totales, se sustraen a cualquier su* jeción empírica.

Las grandes ideas educativas no son sino ideas filosóficas, fruto de la razón dialéctica y resultado de esa "lógica de la ilusión" en que recae inevitablemente el pensamiento, cuando concibe representaciones que han de guiar su actividad práctica. Por ello, tam" bién las grandes ideas educativas pueden ser explicadas genéticamente como el produc. to de una operación totalizadora ${ }^{1}$, a partir de las condiciones de la experiencia.

\footnotetext{
1 Esta expresión se utiliza aquí en sentido kantiano, aunque de un modo más amplio del que tiene en la Crítica de
} 
Ahora bien, cualquier experiencia educativa supone tres condiciones: un educador, un educando y una relación entre ambos. No resulta, pues, ilegítimo suponer que las grandes ideas pedagógicas son el resultado de aplicar, a cada uno de estos elementos, la operación totalizadora de la razón.

Cuando la operación racional afecta al agente de la educación, brota la idea de un educador absoluto, que puede y debe controlar íntegramente la formación del educando, filtrando y disponiendo el conjunto entero de las influencias moldeadoras que van a ejercerse sobre él, así como la serie completa de los contenidos que van a trans. mitírsele. La educación queda, de este modo, subsumida bajo la idea de un Educador Total.

Cuando la operación totalizadora recae sobre el educando, surge la idea de un sujeto íntegramente potenciado por la educación, plenamente desarrollado por ella en todas sus facultades y virtualidades - al menos en aquellas que se consideran genéricas y propias de una hipotética esencia humana-, y capaz, por tanto, de hacer frente y desempeñarse bien ante cualquier situación o tarea. Se obtiene, así, la idea de un Hombre Total, o mejor, de un Educando Total, cuya completitud e integridad humana se concibe como producto de la educación.

Cuando la totalización se ejerce sobre el contenido de la relación pedagógica, éste queda subsumido - de acuerdo con los tres únicos modos posibles de cualquier relación educativa - en tres ideas distintas y alterna. tivas: bien como Instrucción Total, que excluye la formación del carácter; bien como Formación Total, que excluye la instruc. ción, bien como Educación Integral, que in-

\footnotetext{
la Razón Pura. Kant, como es sabido, concebía la razón -de acuerdo con la tradición aristotélico-escolástica- como razón silogistica. Refería siempre, por tanto, Ja totaliza. ción a las premisas de los silogismos - categóricos, hipotéti. $\cos$ y disyuntivos - que entendía estaban en el origen de la síntesis transcendental de las ideas. Pero aquí nos limitaremos a denominar atotalizadora» a aquella operación que to. ma los elementos, siempre particulares, de la experiencia y los transforma en entidades absolucas y perfectas, aunque ideales, y siempre más allá de cualquier experiencia dada.
}

cluirá y conjugará instrucción y formación. Esta última idea se halla muy estrechamente vinculada con la de Educando Total, pues se concibe como la condición misma de posibilidad para la consecución de ese hombre plenamente educado.

Cada una de estas grandes ideas puede recibir y ha recibido, de hecho, determinaciones muy distintas, inspirando prácticas muy diferentes entre sí. Y es examinando estas determinaciones que, a través de la historia, dichas ideas han ido cobrando el cometido principal de esta exposición. Su objeto será mostrar la vida que ha animado a estos esquemas de la razón pedagógica, a esos esqueletos cuyo armazón han sabido revestir las doctrinas educativas. Pero el propósito ulterior será poner de relieve los lín mites internos y las contradicciones a las que conduce cualquier intento de constituir o edificar, por mediación de estas ideas, un programa pedagógico efectivo.

\section{LA IDEA DE EDUCADOR TOTAL}

La idea de Educador Total ha recibido empíricamente, a lo largo de la historia del pensamiento, referenciales diferentes, del mismo modo que la idea de Dios ha alentado distintas religiones positivas y advocacio. nes diversas.

El Estado, la religión, la naturaleza o el mundo social, como instancias educativas, han constituido las más importantes referencias de esta idea.

Parece necesario, pues, analizar sucesivamente estas grandes determinaciones, buscando un paradigma característico de cada una de ellas, ya que examinarlas en toda su amplitud sería imposible en este trabajo.

El modelo platónico de Estado-Educador, el modelo jesuítico de educación religiosa, el naturalismo rousseauniano y el ambientalismo educador de las teorías desescolarizadoras han sido seleccionados como paradig. mas, en el supuesto de que constituyen los exponentes más claros y mejor documentados de la idea de Educador Total. 


\section{El Estado como Educador Total. El paradigma platónico}

El Estado constituye la primera y privilegiada referencia a la idea de Educador Total. No puede extrañar que ello haya ocurrido así. Después de todo, la educación institucional ha surgido históricamente vinculada al Estado. Las primeras escuelas, las de Egipto y Mesopotamia, nacieron como escuelas de escribas, i.e., de administradores del Estado. Cuando la democracia griega concibió la posibilidad de encomendar las tareas administrativas a cualquier ciudadano que estuviese capacitado para desempeñarlas, la educación escolar se hizo extensiva a todos los que pudiesen pagarla. Pero la educación escolar, desde siempre, ha tenido como referencia las tareas de la comunidad civil, en el seno de la ciudad y del Estado. Para bien o para mal, la educación institucional es una consecuencia de la organización estatal y, por ello, el Estado ha sido, a menudo, concebido como la esfera de máximo radio de la educación, como el marco totalizador de un proyecto educativo en el cual se inscriben las escuelas y los educadores.

Siempre que el Estado ha quedado erigido como referencia de la idea de Educador Total, ha sido en función de fines, ellos mismos, totalizadores. Fines como la instauración de la justicia, en la República platónica, ya que la justicia, según observará Hegel (15, vol. II, p. 225) es, en el pensamiento de Platón, «la base o la idea del todo (...), el elemento general que todo lo penetra e informa". Así también, la edificación de la patria alemana en Fichte (12, p. 227) o la implantación y realización del comunismo en la pedagogía marxista.

Por ello, esta idea, en el límite, es inseparable de una concepción monista del conjunto social y nacional. De ahí, por ejemplo, la preocupación platónica por convertir la polis en una unidad orgánica y armónica, así como sus denuncias contra la ciudad empírica, que no es una, sino la reunión de muchas ciudades (36, IV, 442 e), pues en ella coexisten, por lo menos, dos ciudades antagónicas: la ciudad de los ricos y la de los pobres (36, IV, 423-c).
Alcanzar la unidad del Estado que se proyecta exige convertirlo íntegramente en agente educador, de modo que sea el conjunto de la vida política lo que eduque, alcanzando esta educación a todos los ciudadanos, pero también a la vida entera - al alma - de cada uno de ellos. Makarenko, comprometido en el proyecto educativo marxista, cuya semejanza con el platónico se ha subrayado a menudo, expresa bien estas condiciones, cuando observa:

La educación comunista de las masas de millones de soviéticos comenzó desde el primer día de la revolución, desde la primera palabra de Lenin y los primeros combates de los frentes de la guerra civil. Después (...) educación comunista a cada paso, en manifestaciones modestas, imperceptibles (...) aunque en realidad se realizaba de forma consciente y con recta motivación a lo largo de toda la grandiosa experiencia de la construcción socialista. Se puede afirmar literalmente que no hay un solo acto, una palabra o un hecho de nuestra historia que, junto a su significación económica, militar o política, no tuviera también una importancia educativa (25, pp. 56-57).

Ahora bien: si la vida del Estado en su integridad ha de educar para conseguir los fines perseguidos, va a ser preciso depurarla de todos aquellos contenidos, influjos o modelos que no concuerden con la pedagogía buscada. Ello explica la censura, cuya defensa por Platón provoca una conmoción particular en nuestro ánimo, pues iba dirigida, como es sabido, contra la paideia clásica (Cfr. 19, pp. 764-778), es decir, contra la obra de los poetas y dramaturgos griegos, cuya fragancia y belleza, a la que Platón debía ser, sin duda, sensible, no estaban, empero, eximidas de la implacable condena pedagógica.

Parece, asimismo, que el ideario de Estado educador exigía - al menos en su forma límite- la supresión de la familia o, cuanto menos, el control integral por el Estado de la educación de los niños y de su formación profesional. En Platón este control se hace extensivo, como se recordará, a la selección eugenésica de los matrimonios y parejas, así como a la organización de fiestas y celebra- 
ciones que propician los rituales de galanteo entre los jóvenes. Desaparece, pues, cualquier atisbo de vida privada o de intimidad, en una sociedad en la que también la propiedad de bienes - para guardianes y gobernan. tes- habrá sido suprimida.

Resulta explicable que la obra de Platón, todavía en el transcurso de nuestro siglo, haya sido objeto de condenas y ataques tan virulentos. Convencidos de que matar a Pla* tón no era matar a un perro muerto, porque sus ideas constituían la prefiguración más clara del totalitarismo, del estatalismo, pero también del clasismo o del racismo, sinceros liberales, como Popper, han confesado ver. se impelidos a "juzgar a Platón con un espíritu altamente crítico" (37, p. 11) subrayando que, "aun cuando a veces nos referimos al pasado, los problemas tratados son los problemas de nuestra propia época" (37, p. 9). Porque, en la consideración de Popper el historicismo marxista y, en general, toda filosofía política inspirada en Marx, se orienta hacia una "sociedad cerrada", heredera de la que concibió Platón.

Pero acaso las consecuencias aterradoras del modelo platónico, el carácter "cerrado" de la ciudad que propició e, incluso, esos rasgos que tanto han escandalizado a $\mathrm{Fa}$. rrington (11, pp. 88-95): la defensa de la mentira política y la ficción religiosa, al ser. vicio de un clasicismo rígido, no pueden ex* plicarse únicamente como el producto ideológico de la conciencia interesada de un aristócrata, que no pretendía sino defender el predominio de las castas superiores (Cfr. 43, p. 60). Porque, ¿cómo entender, en ese caso, que Platón no se hubiera limitado a propugnar la oligarquía y que, por el contrario, la desacreditara expresamente? ¿Por qué el célebre mito mentiroso recogía la posibilidad de que los propios magistrados de la ciudad tuviesen hijos de bronce y que, de ser así, obedeciendo al mandato de la divinidad, tendrían que destinarlos a la artesanía o a la labranza? (35, III, 415 a-c). Sin duda porque esa ciudad educadora de Platón no es sim. plemente el sueño de un aristócrata con ambiciones, sino más bien el de un filósofo moral, demasiado enamorado de la unidad en su esencia, en la absoluta quietud de su perfección conceptual.

El modelo platónico es, por ello, especialmente paradigmático para ilustrar lo que sucede cuando una idea de la razón quiere ser llevada al extremo final de su pureza. Hay que creer a Platón cuando responde a Adiamanto que no le preocupa particularmente la felicidad de los guerreros $(35, \mathrm{IV}$, 419-a), como tampoco la de los filósofos, que más que nada gozarían en el sosiego de la contemplación (35, VII, 519 d). En su concepto, "es indiferente para la ciudad que exista en ella una clase de hombres privilegiados, pues el objetivo importante es que este honor alcance a todos los ciudadanos" (35, VII, 519-e).

Platón no mentía, sino que decía la verdad cuando afirmaba:

... nuestra meta al fundar un Estado no es hacer particularmente feliz a una clase única de ciudadanos, sino asegurat la mayor dicha posible al Estado entero (IV, 620b).

Sus palabras expresan un convencimiento análogo al que proclamaba Makarenko:

Nuestra ética comunista debe orientarse a la felicidad de millones de hombres y no sólo a la propia (...). En cada uno de nuestros actos debemos pensar en la colectividad, en la victoria general, en el éxito de todos (25, p. 33).

Resulta paradójico, o acaso trágico, que sea precisamente la totalización misma de la idea de felicidad o de justicia, concebidas en su extensión absoluta y en su impecable pu* reza y perfección, lo que haya generado esa concepción pétrea, gélida e indudablemente inquietante, de un Estado como Educador Total.

¿Significa ello que hay que aprender a coexistir con la imperfección, puesto que un mundo absolutamente justo depara, en realidad, la injusticia absoluta? Pero, sin em. bargo, por otra parte ¿cómo un proyecto pedagógico coherente podría renunciar a soñar la perfección para la totalidad? Tal es, en definitiva, el conflicto que desgarra interiormente al Estado educador. 


\section{La religión como Educador Total. El modelo jesuítico}

La religión se ha erigido, a menudo, y se sigue erigiendo en educador absoluto. Pero no es posible examinar aquí el fenómeno religioso en toda la amplitud de su aspira. ción educadora. Necesitaremos, como en el caso del Estado, ceñinnos a un modelo particular, específicamente pedagógico, que sirva de paradigma de educación religiosa sub. sumida bajo la idea de Educador Total.

La pedagogía jesuítica puede desempeñar bien ese cometido paradigmático. Porque el papel de soldados de la Contrarreforma que asumieron los miembros de la Compañía de Jesús (Cfr. 39, pp. 154.155), con su especial voto de obediencia al papa, permite entender la pedagogía jesuítica como directamen. te emanada de una Iglesia - la católicacuyo poder temporal y espiritual compite con el de los Estados, así como con el de las Iglesias rivales, utilizando la pedagogía como una de sus armas principales de proselitismo.

Ya en la formulación de san Agustín, la contienda entre la Ciudad de Dios y la Ciudad del Diablo tenía una indudable dimensión pedagógica: trataba de introducir al catecúmeno en el organismo de una sociedad civil ajena y, a menudo, hostil al cristianismo ( $C f r$. 4, p. 19). Y la ciudad de Dios, es decir, la Iglesia (4, p. 30), encontrará, muchos siglos después, en la Compañía de Jesús, una milicia pedagógica particularmente combativa y eficaz.

La educación jesuítica se orientaba a alcanzar la universalidad del cristianismo. Como advierte Ganss (14, p. 225):

Ignacio miraba la educación como un medio para alcanzar el fin de su Compañía, la salvación y perfección de los estudiantes, para que ellos, a su vez, pudiesen promover la salvación y perfección de sus prójimos, y así, vigorosa e inteligentemente, transformar la sociedad en el espíritu del Reino de Cristo.

Pero dichos fines debían realizarse en el seno del mundo secular, un mundo claramente indiferente, cuando no contrario al catolicismo, un mundo corrompido por el pecado y sembrado de tentaciones demasiado irresistibles para la flaqueza de la carne. Por eso, los jesuitas trataron de asegurarse un influjo pedagógico "total» sobre sus educandos, aislándolos del mundo mediante el internado. La figura del internado ya existía, ciertamente, pero los jesuitas le dieron una función distinta a la puramente residencial y educativa que tenía en los Colegios Mayores. En realidad, lo concibieron como una extensión, en el ámbito de la enseñanza seglar, de la clausura propia de las órdenes religio. sas, es decir, como el medio de acotar un espacio pedagógico sagrado, segregado del mundo y permanentemente vigilado. Como dice Synders (45, p. 39):

La organización del internado no signifi. ca, ni trabajo ininterrumpido, ni disciplina brutal (...) De hecho, la función del inter. nado es instaurar un universo pedagógico, un universo exclusivamente pedagógico y que se caracterizará por dos rasgos esenciales: separación con el mundo y, en el interior de ese recinto reservado, vigilancia constante e ininterrumpida del niño.

La permanente obligación de vigilancia, encomendada, en especial, a los padres prefectos, que no podían perder de vista a sus pupilos a ninguna hora del día, observándolos en el dormitorio, en la sala de estudio, en el refectorio, en los recreos, en la iglesia y en todo momento y situación, recaía, además en defecto de los educadores, sobre los propios escolares: se les amenazaba con un cas* tigo si no delataban al compañero que infringía las normas. De hecho,

la obsesión por lograr una vigilancia eficaz prevalece sobre cualquier otra consideración y el P. Croiset afirmará que el deber de denunciar a un camarada que mantiene conversaciones poco cristianas o que posee libros de galantería no es menos imperioso que el deber de impedir que un contagio $o$ un incendio se propaguen $(45$, p. 41$)$.

La clausura y la vigilancia imponían vacaciones y salidas muy breves, tanto más breves cuanto más jóvenes eran los pupilos. Exigían, asimismo, una rigurosa censura de los libros, censura ordenada por el propio Ignacio de Loyola en las Constituciones de 
la Compañía de Jesús (Parte IV, Cap. 14. Cfr. 24, pp. 543-544), cuidadoso en prohibir toda lectura o incluso todo autor sospechoso de mala doctrina "porque se toma afficción por la obra del autor (...). Es también una cosa rara que algún veneno no se mezcle en lo que sale del pecho lleno dél» $(24$, p. 543). Y se esmeraba en que también los libros de Humanidad, latinos y griegos, fueran "primero limpiados de las cosas y palabras deshonestas" $(24$, p. 544).

Es cierto que, según Foucault (13), no fue la Compañía de Jesús, ni siquiera el catolicismo contrarreformista el que instauró, a partir, sobre todo, del s. XVII, una pedagogía del control y de la vigilancia. Fue la episteme, en su conjunto de toda esta época, la que se caracterizó por un reforzamiento, en todos los ámbitos, de una nueva forma de poder, basado, precisamente, en la utilización sistemática y generalizada de sofisticados métodos de control y vigilancia, como sutiles instrumentos de dominio. $Y$ así, el "papnotismon en las prisiones, en los hospitales, en el ejército, en las escuelas y en las nacientes industrias, habrían servido a los mismos fines de organizar el tiempo, acotar el espacio y pautar los movimientos de cualesquiera subordinados, controlando su rendimiento y su obediencia.

También es cierto, sin embargo, que el propio Foucault relaciona la utilización de todas estas técnicas con una intención nueva, específicamente re-educadora y re-habilitadora para tratar a delincuentes, locos, reclutas u obreros al modo de menores o descarriados, a los que habría que educar o regenerar, haciendo extensivas a las instituciones penales, terapéuticas o militares, los métodos de una pedagogía total y totalizadora.

Es necesario subrayax, de otro lado, que estas técnicas - aislamiento, vigilancia, control, etc. - no están necesariamente ligadas al autoritarismo, sino que son enteramente compatibles con el liberalismo y, acaso, con ciertas formas de libertarismo. Rousseau y Neill - por citar dos exponentes claros de pedagogía de la libertad- han tenido en común una franca hostilidad contra cualquier manifestación autoritaria. $Y$, sin embargo, tal vez precisamente para salvaguar- dar la libertad de educación, han postulado la necesidad de un control lo más absoluto posible del educando, sustrayéndolo del influjo de la familia, aislándolo de la sociedad, según ellos corrompida y enferma, y confinándolo en un aséptico jardín natural.

Por esto mismo, el ideario pedagógico de Rousseau puede constituir el paradigma de una determinación nueva, en la que va a ser la naturaleza la que desempeñe el papel de Educador Total.

\section{La naturaleza como Educador Total. El paradigma rousseauniano}

Se diría que la obra educativa de Rousseau, más que como un tratado de educación, está planteada como un experimento pedagógico y epistemológico ideal, para llegar a conocer cómo se produciría, de modo espontáneo y sin intervención exógena alguna, el proceso natural de la educación. Por eso, Rousseau se procura un "alumno imaginario» -Emilio- que representa la encarnación misma de la naturaleza humana en estado prístino, recomendado a su, también imaginario, preceptor:

Hombre prudente, espiad largamente a la naturaleza, observad bien a vuestro alumno, antes de dirigirle la primera palabra; dejad primero al germen de su carácter en plena libertad para mostrarse, no lo contrariéis en su ser posible, a fin de poderlo ver mejor todo entero (42, p. 84).

De ahí que Rousseau preconice constantemente una educación puramente negativa, una educación que no sea simplemente un "laisser faire», una pura no-intervención, sino que consista en un "ne rien laisser faire" $(42$, p. 83$)$, es decir, en una acción positiva encaminada a impedir toda interferencia pedagógica que pudiera alterax la acción educadora espontánea de la naturaleza sobre el niño.

Ésa es la razón principal por la que los preceptos pedagógicos rousseaunianos consisten, casi siempre, incluso estilística y gramaticalmente hablando, en preceptos negativos, tales como: "no les enseñéis nunca al 
niño nada que no pueda ver» (p. 210); "no le inflijáis ninguna clase de castigo (...); no le hagáis nunca pedir perdón» (p. 81); "no ra" zonéis con vuestro alumno" (p. 83 ), etc. $\mathrm{El}$ cometido de estas negaciones es, siempre, oponerse a alguna de las prácticas pedagógicas vigentes en su época, prácticas que Rousseau conceptúa al modo de auténticos idola, de prejuicios nocivos que, con su ingerencia, alterarían la pureza del experimento pedagógico natural.

Convencido de que el comportamiento de la naturaleza humana está presidido por le. yes de equilibrio, idénticas a las que presiden el mundo de la mecánica, Rousseau tra* ta, a toda costa, de salvaguardar y proteger ese recuerdo armónico que se produce es. pontáneamente entre los deseos del niño y las fuerzas para satisfacerlos, entre su curiosidad intelectual y el desarrollo alcanzado por sus facultades cognoscitivas, entre los intereses de Emilio y las exigencias de su formación, siempre que ninguna ingerencia foránea adultere la acción de la naturaleza.

Para evitar que se produzca alteración alguna en el curso natural del desarrollo, cree necesario aislar al discípulo y mantener al preceptor siempre vigilante, atento a garantizar que sea efectivamente la naturaleza el único y exclusivo educador de Emilio. $\mathrm{Ni}$ siquiera sus padres podrán intervenir en la educación del niño. El preceptor exigirá un control único y absoluto sobre él (Cfr. 42, pp. 27-28); un control ininterrumpido que se prolongará durante todo el período de formación. "No le pierdo de vista ni un momento" - dice (42, p. 25). Y, en efecto, el educador va a tener previsto y preparado de antemano todo cuanto suceda a Emilio: los estímulos que le incitarán a obrar o a apren. der, los obstáculos que encuentre, las situaciones con las que se enfrente - incluso aquellas en apariencia casuales e imprevistas, como perderse en el bosque (Cfr. pp. 204-207) o descubrir el truco de un feriante (pp. 193. 196). Cualquier experiencia habrá de constituir para el niño una lección intelectual y moral. Rousseau se muestra convencido de que ninguno de los detalles de la formación puede, en rigor, abandonarse al azar. Y dice: "No seréis dueño y maestro del niño si no lo sois de todo cuanto le rodea». Pero añade a continuación: "y esa autoridad nunca será suficiente si no está fundada sobre la estima" (42, p. 85). Esta segunda precisión nos advierte, por cierto, de un importante rasgo de la pedagogía de Rousseau, el cual insiste en que el dominio sobre el discípulo sólo surgirá si Emilio se siente libre, nunca vigilado o coaccionado. De ahí la siguiente recomendación:

que crea siempre ser el que manda (le mat́tre) y que siempre lo seáis vos. No existe sujeción más perfecta que la que conserva la apariencia de la libertad; se cautiva, así, a la voluntad misma. El pobre niño que nada sabe, que nada puede, que nada conoce, ¿no se encuentra a vuestra merced? ¿No disponéis de todo lo que le rodea? ¿No sois dueño de afectarle del modo que os plazca? Sus trabajos, sus juegos, sus placeres, sus penas ino están en vuestras manos, sin que él lo sepa? Sin duda, él no debe hacer lo que quiere, sino que debe querer lo que vos queráis que haga; no debe dar un paso que no hayáis previsto; no debe abrir la boca sin que sepáis lo que va a decir (42, p. 121).

Es más, Rousseau confiesa abiertamente querer valerse del afecto y confianza del niño para controlarlo mejor:

Así, no viéndoos atento a contrariarle, no desconfiando de vos, no teniendo nada que esconderos, no os engañará, no os mentirá; se mostrará tal cual es sin temor; podréis estudiarlo a vuestra guisa y disponer en torno a él las lecciones que queráis darle, sin que él sospeche nunca recibir ninguna (42, p. 121).

Un intervencionismo y un control tan ab. solutos resultan perfectamente coherentes y compatibles con una pedagogía autoritaria. No obstante, en Rousseau $-\mathrm{y}$ ésta es una más de sus paradojas- tales condiciones parecen querer sustentar, precisamente, una pedagogía desde la libertad y para la libertad; esa libertad que, según repite constantemente, constituye el más preciado de los bienes del hombre.

¿Cómo logra, entonces, conciliar Rousseau ese control absoluto con el postulado de la 
libertad? Solamente mediante el aislamien. to: creando para su discípulo un universo "natural", un recinto de pureza campestre en el que pueda moverse a su guisa, pero cuidando de que el influjo de la civilización corrompida nunca penetre en ese jardín de inocencia, en ese paraíso infantil.

Rousseau se muestra consciente de la dificultad de este confinamiento, pero no vacila en afirmar la necesidad de asumirlo:

Pero, ¿dónde situaremos a este niño para educarlo así, como un ser insensible, como un au tómata? ¿Le mantendremos en el glo* bo de la luna, en una isla desierta? ¿Le apartaremos de todos los humanos? (...) ¿No verá nunca a otros niños de su edad? ¿No verá a sus padres, sus vecinos, su nodriza, su aya, su lacayo o su propio cuidador que, después de todo, no será un ángel?

Esta objeción es fuerte y sólida. Pero, cos he dicho que fuera una empresa fácil una educación natural? jOh hombres! ¿Es culpa mía si habéis vuelto difícil todo lo que está bien? Soy consciente de estas dificultades y convengo en ellas: quizá son irremontables; pero lo que sí es seguro es que aplicándose a prevenirlas se las previene hasta cierto punto. Yo señalo la meta que hay que proponerse: no digo que se pueda alcanzar; pero digo que quien más se aproxime a ella será el que obtenga mejores resultados $(42$, p. 84).

Tal es, en suma, la paradoja que atraviesa el ideario de una educación plenamente natural: la libertad de la naturaleza infantil exige el confinamiento del niño en la naturaleza. Y educar de acuerdo con la naturaleza exige desnaturalizar la educación.

\section{La Sociedad como Educador Total. El paradigma desescolarizador}

Examinaremos, finalmente, un cuarto pa. radigma de la idea de Educador Total, paradigma que mantiene, sin embargo, importantes diferencias con los anteriormente des. critos ya que, en cierto sentido, constituye su negación. Se trata de la teoría desescola. rizadora, cuyos máximos representantes son, como es sabido, I. Illich y E. Reimer. Dicha teoría se caracteriza, ante todo, por aceptar, a pies juntillas, la posibilidad omnisciente y omnipresente del Educador Total que, bajo la forma de la sociedad tecnológica, y delegando sus poderes en la institución escolar, constituiría -salva veritate - una realidad aterradora que necesitaría ser radicalmente combatida. Las tesis desescolarizadoras representan, pues, la contrapartida contra-institucional de una concepción metafísica de los poderes de la educación.

El mundo ambiental, la vida social en su conjunto, es, para estos autores, el genuino educador de los hombres:

La mayoría de las personas adquieren la mayor parte de sus conocimientos fuera de la escuela (...) Lo principal del aprendizaje sobreviene casualmente $(17$, p. 25$)$.

Pero para que la educación incidental pue" da ejercer con plenitud sus efectos, la escuela y la escolaridad obligatoria habrán de ser suprimidas. Porque, de acuerdo con el análisis de estos autores, la escuela es el más diabólico y eficaz instrumento que la socie" dad tecnológica ha imaginado para mantener el monopolio de la producción y consumo de la enseñanza ( $C$ fr. 38, p. 10), el cual proporciona, a su vez, el sustrato indispensable del monopolio ejercido por la sociedad tecnológica:

El monopolio escolar de la educación se logró debido a que era un aspecto del monopolio. Las escuelas son una garantía de que, en un mundo dominado por la tecnología, aquellos que heredan la influencia serán los que se beneficien de la dominación y, peor aún, los que han sido declarados incapaces de cuestionarla. El juego escolar no sólo moldea líderes, sino también a sus seguidores $(38$, p. 26$)$.

Los partidarios de la desescolarización consideran que la escuela puede desempeñar perfectamente ese papel monopolístico, en la medida en que ha llegado a convertirse en una institución total $(38$, p. 35$)$, que controla, de un modo absoluto, tanto a los sujetos que pasan por ella como a los desertores o, incluso, a quienes nunca pisaron las aulas. A 
todos ellos, la escuela promete el único modo de salvación posible: el de la educación escolar que ella misma monopoliza. Por eso, la escuela es enjuiciada por Illich (17, p. 62) como "la Iglesia universal de nuestra decadente cultura", una iglesia mucho más insidiosa y potente que cualquier otra, por estar dotada de mayor podex sobre la vida material y social de sus adeptos $(38$, p.26).

La escuela controla, pues, de modo integral, los destinos de quienes asisten a ella; además "por su naturaleza misma, tiende a reclamar la totalidad del tiempo y de las energías de sus participantes» (17, p. 47). Y esto lo consigue encerrando a los niños de cierta edad en las instituciones educativas, suspendiéndoles de toda autonomía y de todo derecho - excepto la de consumir la mercancía del conocimiento que ella misma les proporciona - y prolongando su minoría de edad mucho más allá de lo legítimo y razonable. La escuela desempena, por otra parte, un papel selectivo, encargándose de "colocar a los jóvenes en los casilleros que ocuparán cuando les Hegue la edad adulta» (38, p. 36), y convirtiéndose en "el principal mecanismo para distribuir valores de toda clase entre los pueblos del mundo" $(38$, p. 38).

Si a ello se añade la función de adoctrinamiento, por la cual la escuela enseña que únicamente vale lo que se aprende o se adquiere en la escuela, desalentando, con ello, toda creatividad, todo autoaprendizaje, se comprenderá, según Reimer (38, p. 24), por qué «una pequeña dosis de escolarización puede inducir una gran cantidad de insatisfacción». Aunque, según estos autores, para ser adoctrinado por la escuela, ni siquiera hace falta haber pasado por ella:

La mitad de la gente de nuestro mundo jamás ha estado en una escuela (...) Y, no obstante, aprenden eficazmente el mensaje que la escuela enseña: el que deben tener escuela, y más y más escuela. La escuela les instruye acerca de su propia inferioridad (..). De modo que a los pobres se les quita el respeto a sí mismos al suscribirse a un credo que concede la saivación sólo a través de la escuela $(17$, p. 46$)$.

Estas y muchas otras razones aducen Illich y Reimer para probar que la institución escolar, sea privada o pública, religiosa o laica, desempeña un monopolio de la educación tanto más peligroso cuanto que invalida y quita prestigio al verdadero agente de toda educación auténtica: al mundo social, laboral y profesional, donde se llevan a cabo, en realidad, los únicos aprendizajes importantes y valiosos.

Por ello mismo, y para restituir sus derechos a la educación incidental, dichos autores exigen la supresión de las escuelas y to. do tipo de instituciones similares, como primer paso para devolver a la sociedad, globalmente considerada, su genuina función educadora.

La disolución de la escuela deberá, sin embargo, prolongarse en una reorganización de la propia sociedad, de acuerdo con un modelo "convivencial» ( 18$)$, para que "todo en ella -objetos, máquinas, libros, aparatos audiovisuales, talleres, fábricas, personas, etc...- convenientemente organizado en "redes" que hagan asequibles esos bienes a cualquiera que desee utilizarlos, sea puesto al servicio de la educación. Con lo que "todo", a la postre, quedará convertido en institución educativa, pero no escolar.

\section{Límites de la idea de Educador Total}

Las cuatro grandes determinaciones de la idea de Educador Total que acabamos de exarninar, contienen elementos comunes. Las tres primeras exigen la acotación de un espacio educativo - el del Estado, el del colegio, el del jardín natural-, dentro del cual todo contenido ha de ser edificante y ha de estar programado, previsto y controlado. El espacio de la educación es espacio sagrado, y por tanto necesita ser protegido de toda posible profanación exterior, es decir, aislado o clausurado, para que su pureza no sufra merma, a causa de incidencias extrañas. $Y$ así, Platón exige la autarquía para su República, los jesuitas fomentan el internado en sus colegios y Rousseau propone el aislamiento de Emilio en la campiña.

La teoría desescolarizadora es, en este sentido, antagonista de las tres anteriores y su- 
pone la negación de cualquier espacio acotado para la educación, de cualquier reducto o recinto donde se concentren e intensifiquen las experiencias educativas. Constituye, en realidad, el resultado de invertir el espacio escolar. Para Reimer e Illich, todo espacio es educativo excepto, justamente, el de la escuela. Porque la escuela, como "reserva" donde se confina la educación es, según el concepto de estos autores, el espacio deseducador por excelencia.

En cualquier caso, las teorías expuestas ofrecen exponentes diversos de una misma operación totalizadora, por la cual, la razón pedagógica aspira a ejercerse íntegramente como educador absoluto.

Cada una de las diferentes acepciones de Educador Total posee, sin embargo, sus límites internos. Y esos límites han sido, de hecho, siempre perceptibles. Por eso, toda doctrina pedagógica que ha querido ejercerse - a través del Estado, de la naturaleza, etc. - como instancia educadora integral, ha propiciado, correlativamente, ciertos correctivos o medidas, en principio indeseables -el aislamiento, la clausura, la censura...en un intento, nunca completamente eficaz, de evitar aquello que pudiera disgregar o corromper la unidad de su proyecto.

El límite del Estado en cuanto agente educador total es -según Platón mismo supo percibir- Ia pluralidad interna constitutiva de la ciudad o del Estado. Porque ni el Estado ni la ciudad son nunca algo monolítico y simple, sino una realidad compleja, cruzada de antagonismos y cuya diversidad de clases sociales, de intereses, de pasiones, de ideologías o de designios no puede ser fácilmente reducida a la unidad.

Platón partía del reconocimiento de esa pluralidad, puesto que ponía el origen de la ciudad precisamente en la división del trabajo. Esa división del trabajo, generadora de riqueza, haría, además, inevitable el crecimiento de la ciudad, de sus bienes y necesidades, engendrando, correlativamente, el lujo, el parasitismo y la voluptuosidad. Y con ello, claro está, se produciría la división misma de la ciudad, cuya unidad quedaría rota, enfrentando en su seno varias ciudades distintas - la de los ricos y la de los pobres, la de los productores y la de los parásitos-. Contra esa pluralidad quería luchar Platón, organizando las diferentes partes de la ciudad -sus oficios, sus clases sociales, sus individuos, sus funciones- en un conjunto armónico y unitario. Mas Platón era consciente de que el equilibrio de la justicia habría de ser, en la polis, siempre inestable, oscilando entre la timocracia, la oligarquía, la democracia y la tiranía, en una pugna sucesiva de cada fracción sobre las demás. La supresión de la propiedad privada o de la familia, la instauración de la censura y de la mentira política, la autarquía de la República y el sometimiento de las clases superiores a las tareas más nobles, pero también más exigentes y desinteresadas - el gobierno, la educación y la defensa de la ciudad-constituían, en su proyecto, los correctivos indis. pensables contra esas fuerzas disgregadoras que adivinaba inevitables.

El modelo platónico de Estado-educador, como figura paradigmática de uno de esos monstruos que, en sus ensoñaciones, produce la razón pedagógica, nos ilustra de los peligros que conlleva la idea de educación estatal llevada a sus últimas consecuencias.

La educación religiosa, cuando quiere erigirse en instancia pedagógica totalizadora, encuentra sus límites en lo profano, en lo secular, en esa Babilonia diabólica en la que san Agustín veía peregrinar a sus creyentes, siempre a la búsqueda de Jerusalén, pero confundidos con el siglo y entremezclados con sus moradores, como el trigo con la paja. Por eso la religión ha creado el cenobio, el convento, el monasterio, buscando en el aislamiento o en la clausura, una protección contra el mundo y sus tentaciones. Pero cuando la clausura y el internado no se destinan a quienes buscan huir del mundo, sino a los niños y jóvenes que han de ser preparados y educados para vivir en él, la situación pedagógica creada resulta especialmente paradójica y autocontradictoria. Ello puede quedar ilustrado por las inconsecuencias internas de los colegios jesuíticos. Dentro de aquel universo pedagógico, purifica do de toda pasión secular, fue preciso crear una estructura artificial de pasiones escolares, en torno a la emulación (45, pp. 48-54). 
Para alentarla, reinventaron un mundo ficticio, con sus guerras entre romanos y cartagineses, sus pompas, sus títulos y jerarquías. Ello daba pie, entre los escolares, a un tumulto de rivalidades, de envidias, de vanidad, insolidaridad y delación, acaso más virulento y peligroso que aquel otro - el mundo exterior y profanom cuyo influjo sobre los niños pretendían evitar.

Análogos límites y contradicciones internas conlleva la idea de naturaleza como educador, al modo en que la concibió Rousseau. El ginebrino creía poner las bases del conocimiento experimental de la educación, al imaginar la supresión de todo influjo educativo. Confeccionó, en efecto, su programa pedagógico, en la convicción de que, si para conocer la naturaleza física y para liegar a dominarla mediante la técnica, era preciso - siguiendo el lema de Bacon-- obedecer sus leyes y dejar que éstas se manifestaran en su verdad, sin alterarlas con vanos prejuicios (idola), así también, para conocer la naturaleza humana y dominarla mediante la educación, habría que actuar con parecida cautela.

Pero, precisamente en nombre de su naturalismo, Rousseau falseaba, en su experimento pedagógico ideal, las condiciones naturales en cuyo contexto se produce siempre la educación. Y así, considerando en la educación de Emilio, de un modo unilateral y exclusivo, aquellas variables que dependen de la maduración psicobiológica, situaba a su educando en un «laboratorio pedagógico» incompleto, en el que dejaba, ciertamente, actuar a las cosas, a los objetos, pero abolía, en cambio, la acción educadora positiva de los hombres. Con ello, su "experimento ideals, queriendo ser natural, resultaba profundamente artificioso y ficticio, pues toda educación se produce naturalmente dentro de la sociedad y de sus instituciones. La eđucación natural, a la postre, es la más antinatural de las educaciones concebibles.

Resta, por último, analizax la contradicción en que incurren las corrientes desescolarizadoras, que es particularmente poderosa. Porque los partidarios de la desescolarización preconizan la desaparición de la escuela, al suponer que, siendo la educación omni- presente, institucionalizaria significa tanto como atentar contra ella. Utilizan el mismo argumento del místico contra el sacerdote: "¿Cómo atreverse a encerrar a Dios, que es ubicuo, en los templos?" A modo de panteístas de la educación, Illich y Reimer protestan porque, lo que es ubicuo quiera encerrarse en los templos de la enseñanza, en instituciones educativas.

No obstante, a fuer de oponerse a institucionalizar la educación, y en el supuesto de que el mundo ambiental en su conjunto es educativo, los fundadores del C.I.D.O.C. terminan por ofrecer unas propuestas pedagógicas que vienen a equivaler, en realidad, a la institucionalización misma del ambiente social en todos sus elementos. La sociedad en su conjunto quedaría, así, paradójicamente, convertida en una Escuela Total.

\section{LA IDEA DE EDUCANDO TOTAL}

Decíamos en páginas anteriores que, cuando la operación totalizadora de la razón pedagógica se ejerce, no sobre el emisor, sino sobre el receptor de la educación, surge la idea de un Educando Total, es decir la idea de un sujeto íntegramente potenciado por la educación y desarrollado en toda la gama de sus facultades o de sus virtualidades. Al menos de las virtualidades que se consideran genéricas y características de la naturaleza humana.

Ahora bien, como el concepto de "naturaleza humana" es, él mismo, una idea cuyos parámetros son distintos en cada momento histórico y doctrinal, la idea de Educando Total adquiere, a través de la evolución del pensamiento pedagógico, diferentes determinaciones, en concomitancia con diferentes modelos antropológicos.

Max Scheler (44) ha creído poder distinguir cinco grandes determinaciones de la idea del hombre: la idea judeo-cristiana de hombre, como hijo de Dios, creado por Él a su imagen y semejanza, caído en el pecado y redimido; la idea griega de hombre como bomo sapiens, acuñada por Anaxágoras, Platón y Aristóteles, en la que la esencia humana aparece definida por el logos, por la raciona- 
lidad; la idea naturalista del hombre, que lo define como bomo faber, es decir, como un animal más cuya inteligencia práctica se halla al servicio de las necesidades que, como animal, lo caracterizan: alimentación, reproducción y poderío; la idea pesimista del hombre como ser enfermo, decadente, de sertor de la vida; finalmente, la idea del superhombre, en la cual prevalece la exaltación suprema de su soberanía.

Pero las ideas de hombre que el pensamiento pedagógico ha ido autoproponién dose como modelos de educando integral no se corresponden puntualmente con estas cinco grandes ideas. Sin duda están relacionadas con ellas, pero no son intemporales y carecen, por tanto, de esa validez general y abstracta que tienen en Scheler, aunque, ciertamente, con frecuencia han sido propuestas como si, en efecto, tuviesen esa validez universal.

No podemos estudiar con el detalle necesario todos los referenciales históricos de esta idea de Educando Total. A modo de ejemplos más paradigmáticos considerare mos sumariamente los que se dieron en la paideia griega, en el cristianismo medieval, en la obra de Comenio y en la teoría marxista. Todos están concebidos de acuerdo con un modelo genérico y esencialista de hombre. pudiera ser interesante, sin embargo, resenar que la idea de Educando Total ha sido pensada, también, a partir de esquemas substancialistas, individualistas o monadológicos. Asílocurre en Rousseau o en Neill. En sus respectivas teorías, el hombre genérico es aquél que llega a ser "el mismo" y que realiza todas las potencialidades propias de su carácter y de su genio. Esta segunda idea la consideraremos, sin embargo, sólo someramente y para contrastar la primera, porque de otro modo la exposición se alargaría demasiado.

\section{El modelo de la areté en la paideia griega}

En el seno de la paideia clásica, tal y como Jaeger la ha analizado, el concepto de areté, que resumía la excelencia humana, fue moldeándose y cambiando, aunque conservase siempre la huella de la época heroica, que cifraba la virtud en el ideario de la kalokagatbia. Porque la belleza y rectitud moral - como exigencias genéricas de la educación integral del hombre griego- fueron concretándose en modulaciones diferentes desde $\mathrm{Ho}$ mero a Píndaro, de éste a Simónides o a Sófocles, pero también dentro de la propia sofística, en el platonismo, etc.

Tanto el valor que acredita la victoria del atleta, como la belleza conquistada mediante la disciplina gimnástica, o la justicia, entendida como veneración a los nomoi de la ciudad, o el propio logos, es decir, la inteligencia racional, según se revela en el len. guaje, en el pensamiento o en la acción, desempeñaron entre los griegos el papel de contenidos privilegiados de la areté o de ma* nifestaciones suyas.

Jaeger menciona la extrañeza del posterior pensamiento cristiano ante las virtudes griegas y, sobre todo, ante las virtudes políticas:

El origen de la ética filosófica de Platón y de Aristóteles en la ética de la vieja polis no fue conocido por los tiempos posteriores (...). Cuando la iglesia cristiana comenzó a considerarla, halló sorprendente que Platón y Aristóteles mencionaran el valor y la justicia como virtudes morales. $Y$ tuvo que habérselas con este hecho originario de la conciencia moral de los griegos. Para una generación ajena a la comunidad política y al Estado, en el sentido antiguo de la palabra y desde el punto de vista de una ética puramente individual y religiosa, no era comprensible más que como una paradoja. Así, compusieron disertaciones doctorales sin fin sobre el problema de si el valor es una virtud y cómo es posible que lo sea (19, p. 110).

Porque, entre los cristianos, el hombre que se propone como modelo de toda educación es Cristo, que dista mucho del héroe victorioso y bello como una escultura de los himnos de Píndaro, pero también se halla a mucha distancia del ciudadano virtuoso y elocuente de la sofística, del filósofo platónico o del sabio contemplativo aristotélico. 


\section{El modelo cristiano}

La figura de Cristo, como modelo del magisterio cristiano, hubiera parecido a los clá sicos la del antihéroe. Porque los griegos habían vinculado siempre la virtud a la eudai. monia: en su concepto, el hombre perfecto y virtuoso no podía menos que ser un hombre feliz. Sólo la desmesura podía conducir al héroe a la tragedia. Pero la ciencia de la medida -secreto de la virtud-- será también la clave de la dicha. Así lo subrayará Platón y sobre todo Aristóteles: la perfección, el equilibrio, eran la condición de la pleni. tud y alegría. Por eso decía Aristóteles que "la felicidad no puede encontrarse en el niño, ni éste puede ser dichoso, lo cual tiene lugar exclusivamente en el hombre formado, porque es un ser completo" (Gran Ética, I, 4). La verdadera felicidad exigía, según Aristóteles, dos condiciones: una virtud com. pleta y una vida plenamente desarrollada. Pero, a la vez, la vida virtuosa no era posible, según él, en el absoluto infortunio (Ética o Nicómaco I, VIII, pp. 48-49).

Para el ideal cristiano, en cambio, el hom. bre perfecto es aquel que, a imitación de Cristo, asume voluntariamente la pobreza y el sufrimiento, desprecia el mundo y su sa* biduría, se vuelve humilde y se hace herma* no de los más desventurados, de los miserables, los enfermos, los débiles y los niños ${ }^{2}$.

Se comprende bien el coraje y la irritación de Nietzsche contra el modelo cristiano de humanidad, cuando afirmaba:

Al cristianismo no se le debe adornar ni engalanar: él ha hecho una guerra a muerte a ese tipo superior de hombre, él ha proscrito todos los instintos fundamentales de ese tipo (...). El cristianismo ha tomado partido por todo lo débili, bajo, malogrado; ha hecho un ideal de la contradicción a los instintos de conservación de la vida fuerte (34, pp. 2930).

El cristianismo medieval, en efecto, mo. deló durante siglos su ideal de hombre mediante la negación de todo cuanto pudiese

\footnotetext{
2 Resulta tevelador que el cristianismo, a diferencia de Aristóteles, proponga como modelo a los niños: «Haceos co. mo niños", etc.
}

dignificar al sujeto humano. Cristo, humilde y doliente, sometido a tentaciones, vejado y humillado, víctima del escarnio y del tormento, se convierte en paradigma, en maestro, en "camino, verdad y vida". Por eso, ser educado según el modelo cristiano significará imitar a Cristo. Y justamente la Imita ción de Cristo (22), atribuida a T. Kempis, que se conceptúa como la mejor síntesis de la ascética y mística medievales, es una buena guía para entender el ideario de conducta cristiana. Un ideario que constituye, por cierto, la contrafigura o el reverso de esta idea pedagógica que analizamos, puesto que, por una parte, recuperando la tradición del $D e$ Magistro agustiniano, invalida toda enseñanza que no sea la propia voz de Dios, en el fondo del alma y, por otra parte, lejos de orientarse a la edificación del hombre, a su formación, busca, por el contrario, su ani. quilación en Cristo. En nombre de ese idea* rio, Kempis advierte contra "el deseo inmo. derado de saber", ya que "ide qué vale la ciencia sino de distracción y engaño?" (22, $I, 2,3)$, el «tenerse a sí mismo como en nada» $(22, \mathrm{I}, 2,14)$.

Kempis recomienda vivir sobre la tierra como "un desterrado y peregrino» (22, $1,17,3)$, ahondando en el dolor y en la com punción: «El hombre bueno encuentra siempre materia suficiente para dolerse y llorar" $(I, 21,18)$. Pues el cristianismo "ha de nutrir. se del pan de las lágrimas y beber en el llanto de la abundancia" $(22, \mathrm{I}, 21,24)$, ya que "tarnbién Cristo fue despreciado en este mundo por los hombres» (II, 1, 18). "Persuadirse de que la vida debe ser un continuo morir" (22, II, 12, 52), solazarse en la cruz y el martirio: tal es el camino para parecerse a Cristo.

El cristianismo durante muchos siglos re. presentó, como supo ver Hegel (16, p. 345), la negación de la educación: hizo, de ese "conducir hacia algo", un conducir hacia dentro de sí mismo, para aceptarse como indigente y vano y para asumir la desdicha exterior como "dolor íntimo del hombre", o la desgracia como "desgracia de su propia naturaleza, que es en sí misma lo escindido y lo discordante». Así, el cristianismo convirtió la dignidad de ser hijo de Dios en la indignidad de ser hombre. 


\section{El modelo de Comenio}

El pensamiento cristiano supo producir, sin embargo, ya en plena Contrarreforma, a través del magnánimo espíritu de Comenio, saturado de esencias renacentistas y de un amor pleno hacia la naturaleza, muy próximo al del panteísmo de Bruno, una de las más bellas determinaciones de la idea de Educando Total.

Comenio, a quien las guerras de religión causaron tantas persecuciones y destierros, supo afrontar la adversidad con el talante admirable y la serena paz de quien confía, sin embargo, en que el universo, como obra de Dios, está regido por leyes de orden y armonía $(6$, XIII, 14), y de que «el hombre mismo no es sino armonía, tanto respecto del cuerpo como del alma» $(6, V, 19)$. Esta convicción le permitió asumir para el cris" tianismo reformado el ideal renacentista del hombre total y totaimente reconciliado con el mundo de la naturaleza. De ahí que concibiese las escuelas como "talleres de hu" manidad", destinadas a "laborar porque los hombres se hagan verdaderamente hom. bres" $(6, \mathrm{X}, 3)$.

Su radical optimismo pedagógico, al igual que su optimismo metafísico, que inspirará el de Leibniz, tenía raíces claramente reli. giosas. Precisamente porque el hombre había sido creado como imagen de Dios, de forma necesaria representaba y reproducía, según Comenio, los rasgos de su modelo, pues «de otro modo no sería verdadera imagen" ( $\sigma$, IV, 4). Y así, semejante al Dios omnisciente, describía Comenio al hombre "colocado en medio de las obras de Dios, teniendo su luminoso entendimiento a la manera de un espejo esférico suspendido en lo alto, que reproduce las imágenes de todas las cosas, es decir, de todo lo que le rodea" $(6$. VI, 4). De estas premisas deducía el pedagogo moravo la posibilidad de uenseñar todo a todos y totalmente" $(6, \mathrm{X}, 1)$.

Educar a los hombres en todo significaba para Comenio educarles "en todas sus partes y en todas las cosas que perfeccionan la naturaleza humana" $(5$, III, I). Y la naturaleza exa, en su concepto, "no la corrupción inherente a todos después del pecado (...) sino nuestra primera y fundamental constitución, a la que hemos de volver» $(6, V, 1)$. Esa primera y fundamental constitución para la que el hombre fue creado es, en el concepto de Comenio, convertirse en reflejo de la naturaleza divina. De hecho, como imagen de la Trinidad que es, el hombre posee tres potencias: Entendimiento, Voluntad y Memoria, que se manifiestan, respectivamente, en el Pensamiento, la Obra y la Palabra. La educación tendrá, pues, que desarrollar "los tres adornos del alma: Erudición, Virtud y Piedad» $(6, \mathrm{X}, 7)$. Y todo ello con un triple fin: "para conocer las cosas que se ofrecen a la contemplación, en este admirable anfiteatro"; para "hacer lo que se le presente hacedero" y para "gozar de todo aquello que el Criador, con generosa mano, le ofrece al hombre como huésped de su casa" $(6, \mathrm{X}, 5)$.

Dios - dice Comenio - destinó la creación para deleite del hombre. Por ello la educación ha de enseñar a gozar de cuantos bienes provienen de Êl, es decir: ha de enseñar a disfrutar «los pensamientos que experimenta el varón sabio", quien "en todas partes $y$ en todas las cosas encuentra pensamientos de tanta alegría que, a menudo, arrobado y fuera de sí, se olvida de sí mismo"; "del deleite en uno mismo (...) que experimenta el hombre dado a la virtud", para quien "la buena conciencia es un perpetuo banquete». $Y$, finalmente, "del deleite en Dios"s $(6,12,25)$.

Pero, educar al hombre totalmente significa educarle, no sólo en sus tres facultades, sino uen sus relaciones con las criaturas inferiores, con sus semejantes los hombres y con el propio Dios» (S, III, X). Significa, asímismo, "educarle en todos sus deseos, esos deseos que, si Dios, que no hace nada en vano, ha inscrito, como instintos, en la propia naturaleza humana, ello no puede haber sido inútilmente" (5, III, XI-XII).

Comenio supo, pues, ofrecer a la Pedagogía un esquema de Educando Total que, aunque elaborado a partir del ideario cristiano, reconciliaba de nuevo al hombre con el mundo y consigo mismo, de acuerdo con ese modelo de humanidad integral que se había gestado durante el Renacimiento. 


\section{El modelo marxista}

Otro paradigma de la idea de Educando como Hombre Total, acaso el que ha tenido y tiene mayor vigencia en la época contemporánea, es el preconizado por el marxismo, concebido como una réplica a la unilateridad producida por la división del trabajo. Ya en La Ideologta alemana, Marx y Engels (28, p. 34) sonaban el paso a la sociedad comu. nista

donde cada individuo no tiene acotado un círculo exclusivo de actividades, sino que puede desarrollar sus aptitudes en la rama que mejor le parezca; la sociedad se encarga de regular la producción general, con lo que hace cabalmente posible que yo pueda dedicarme hoy a esto y mañana a aquello, que pueda por la mañana cazar, por la tarde pescar y por la noche apacentar el ganado y, después de comer, si me place, dedicarme a criticar, sin necesidad de ser exclusivamente cazador, pescador, pastor o crítico, se. gún los casos.

Para suprimir ese "carácter unilateral" que imprime en cada individuo la división del trabajo y, con ella "toda diferencia de clase", así como la oposición entre la ciudad y el campo, Engels propondrá en los Principios del Comunismo (9, p. 432) una educación politécnica, que permita recorrer a los jóvenes "todo el sistema productivo", pasando sucesivamente por todas las ramas de la pro* ducción.

También Lenin (10, pp. 40-41) proponía un sistema capaz de "educar, instruir y for mar hombres universalmente desarrollados y universalmente preparados, hombres que sabrán hacer de todo".

\section{Limites de la idea de Educando Total}

Los modelos examinados no son todos los posibles, pero sí los que más significativamente hacen referencia a la idea de Educando Total. Todos ellos aspiran a educar a un sujeto capaz de desempeñarse bien ante cualquier situación humana, de enfrentarse a cualquier ambiente, de realizar cualquier actividad, de personificar lo que el propio Rousseau conceptuaba como «la vocación común al estado de hombre" (42, p. 234). En cambio, la educación del hombre total raramente ha sido concebida como una educación enciclopédica: no se trata de enseñar omni re scibile, ni de adiestrar en todos los oficios, sino de formar en el educando la esencia genérica de la humanidad.

Las contradicciones implícitas en la idea de Educando Total proceden de la imposibilidad de llevarla a la práctica. Ante todo, por el hecho de que no existe el hombre genérico: la suposición de una esencia humana que la educación debería potenciar, aproximándose a realizarla lo más plenamente posible, es una suposición metafísica, que se disuelve en cuanto trata de ser aplicada. Porque, ciertamente, existen diferentes modelos de humanidad, pero siempre plurales y empíricamente determinados por el momento histórico y por las necesidades y funciones de cada sociedad. Pero no hay nada en el hombre - ni siquiera la racionalidad - - que pueda ser elevado a objetivo universal por cualquier ideario educativo. (De hecho, tanto el cristianismo como el modelo nietzs. cheano del superhombre han puesto la esen. cia genérica del hombre en valores distintos de la razón). Por éllo cabe decir, con Dilthey:

Lo que el hombre sea lo sabe sólo en el desarrollo de su ser a través de los siglos, pero nunca hasta su última palabra y nunca, tampoco, en conceptos de validez general (...). Por eso el fin último de la vida humana nunca puede ser expresado en conceptos (...). Por eso, tampoco, puede ser reducido a ninguna fórmula el fin de la educación (8, p. 20).

Es posible que las interminables discusiones a que dio origen, entre los griegos, el contenido de la areté y la repetida ironía de Sócrates frente a sofistas que, como Protágoras o Hipias, aspiraban a educar al hombre total o al ciudadano perfecto, tengan, co. mo transfondo, la evidencia de que no exis. te una esencia humana simple y armónica, que pueda conjugar en sí todas las virtudes posibles. Quizás por ello Platón tendió, más bien, a concebir al hombre como habiendo 
nacido especialista (Cfr. 35 II, 670 a-b) y trasladó, en cambio, a la ciudad, esa irrenunciable aspiración a la armonía y a la ple. nitud.

Pero la concepción de la naturaleza humana como la de un especialista es tan hipostática, tan inauténtica y, sobre todo, tan insatisfactoria como irrealizable es la idea de hombre integral. Por eso la pedagogía raramente suele conformarse con proposiciones tan modestas como la de Voltaire, quien recomendaba: "Cada uno debe apren" der, desde niño, lo que le sirve para desem. peñar la profesión que piensa ejercer" (47, p. 220. Sub voce educación).

La recomendación de Voltaire propicia, por su parte, esa suposición substancialista, tan inconsistente como la esencialista, por la que cada hombre se concibe como un ser absolutamente único, una mónada cuya vocación se halla inscrita en su propia sustan. cia individual. La educación, en este caso, tendría el cometido de convertir en acto las potencialidades de cada individuo. El lema de la pedagogía sería, pues, esa versión sui generis del "sé quien eres» de Píndaro que queda, efectivamente, traducido en el lema rousseauniano: "cada espíritu tiene su forma propia, según la cual ha de ser educado" ( 42 , p. 83), pero también en el «dejad que el niño sea él mismo" de Neill (33, p. 241). Rousseau no descartaba, sino que presuponía conse. guir, de este modo, un hombre universal, que no sería soldado, sacerdote, ni magistrado, sino "primeramente hombre" y del cual afirmaba:

Todo lo que el hombre debe ser, sabrá serlo de acuerdo con las necesidades, tan bien como cualquiera; y aunque la fortuna le haga cambiar de sitio, él siempre estará en el suyo (42, p. 12).

En general, sin embargo, la suposición substancialista conduce a una visión muy peculiar del hombre abstracto, el cual aparece ahora, en palabras de Whitehead (48, p. 27) como "un especialista por naturaleza".

Pero la especialización constituye para la pedagogía una nueva fuente de problemas y dificultades (Cfr. 48. ibid.). Y ello porque la realización parcial del ser humano sólo se consigue mediante una reducción y una mu* tilación de la vida psíquica, que difícilmente puede convertirse en objetivo deseable. El propio Marcuse en El Hombre unidimensional (26) ha puesto de relieve hasta qué punto la unilateralidad impuesta por la sociedad in. dustrial avanzada es causa de derrota, de represión y de infelicidad humana.

Resulta así que la realización total del hombre mediante la educación es un ideal inalcanzable, pero la renuncia a ese ideal es, siempre, insatisfactoria. Por ello la historia de la pedagogía exhibe numerosos intentos de educar a un hombre total, pero reduciendo esa totalidad a límites realmente mo. destos. No se puede interpretar de otro modo el hecho de que, incluso los proyectos más deslumbrantes y ambiciosos de Educando integral contengan correctivos internos destinados a salvar el hiato entre el ideal y sus efectivas probabilidades de ejecución.

Así, por ejemplo, el propio Comenio, sin renunciar al proyecto, que define su Didáctica Magna, de «enseñarlo todo a todos y totalmente", especifica, sin embargo $(6, \mathrm{X}, 1)$ :

No ha de entenderse con esto que juzguemos necesario que todos tengan conocimientos (especialmente acabados y laboriosos) de todas las ciencias y artes. Esto, ni es útil por su misma naturaleza, ni posible, dada la brevedad de la humana existencia (...) Por tanto, todos los que hemos venido a este mundo, no sólo como espectadores, sino también como actores, debemos ser enseñados e instruidos acerca de los fundamentos, razones y fines de las principales cosas que existen y se crean.

Constituye una considerable reducción de la omnisciencia -esa omnisciencia que hacia al hombre semejante a Dios- el limitarla al conocimiento de «los fundamentos, razones y fines de las principales cosas que existen". Pero, además, ¿cómo determinar cuáles son esas cosas principales? Dicha determinación consistirá, inevitablemente, en una restricción y paralización del ideal de la pansofía y, en definitiva, en la negación y en la quiebra de dicho ideal. 
La misma suerte ha seguido la seductora idea marxista del hombre omnilateral. Su determinación, a través de la instrucción politécnica, lo convierte, a lo sumo, en un obrero ilustrado y versátil, que recorre las principales ramas de la producción industrial ( 9 , p. 432) o, incluso, según Krupskaia (23, p. 164), tan sólo una de ellas - por ejemplo, la rama textil- aunque procurando que llegue a conocerla con la mayor amplitud y profundidad posibles. En todo caso, la educación politécnica se halla muy lejos de garantizar la formación de ese hombre que, según lo habían descrito Marx y Engels, podría ser simultáneamente pastor, pescador, cazador y crítico.

\section{LA RELACIÓN PEDAGÓGICA COMO IDEA TOTAL}

El tercer tipo de totalización posible a la que conduce el concepto de educación, no es unívoca, como las anteriores, sino que puede adoptar tres modalidades diferentes. $\mathrm{Y}$ esto ocurre porque la telación pedagógica es algo puramente formal y todavía más indeterminado que el educador o el educado como condiciones de la experiencia educativa. Necesita pues, mucho más que éstos, ser especificada en su contenido y en sus fines.

Sin embargo, las propias condiciones de la experiencia permiten concebirla únicamente según tres contenidos genéricos: en la dirección de la «instrucción» o cultivo de la inteligencia; en la dirección de la «formación del carácter" y en una tercera que concilia a una y otra, en la dirección de una "educación integral».

\section{Instrucción Total}

Cuando la relación pedagógica se concibe como totalmente instructiva, esa totalización excluye la posibilidad o la conveniencia de la formación del carácter. Es necesario, sin embargo, distinguir aquellas otras que se limitan a postular la inconveniencia de dicha formación. Esta diferencia no es irrelevante y deriva del extremo en donde se apoya la relación pedagógica. Como quiera que, en cuanto relación, exige, por lo menos, dos términos -educador y educando-resulta posible contemplarla tanto desde el punto de vista del emisor como del receptor. La relación se vuelve imposible cuando ni siquie. ra puede sex emitida. La relación se torna, en cambio, inconveniente cuando, aunque pueda ser emitida, sus efectos sobre el receptor se consideran nocivos o dañinos.

Sólo así cabe entender la diferencia entre aquellas teorías que niegan la posibilidad de la educación, por considerar que el educadot no puede hace otra cosa que instruir (enseñar a tocar la flauta, como Ortágoras, o enseñar a pintar, como Zeuxipo, pero nun. ca enseñar la virtud - como inicialmente parecía defender Sócrates, frente a Protágo ras, en el diálogo platónico $(36,318$ b - 319. e-), y entre aquellas otras teorías que, aun admitiendo que la educación puede, en efecto, ser ejercida, consideran que dicho ejercicio resulta enteramente perjudicial para el receptor de la misma.

Cabe mencionar, en este segundo caso, la posición de Condorcet, quien, en su intento de definir la "naturaleza y objeto de la instrucción pública», de acuerdo con los cánones de la Revolución francesa, establecía que «la educación pública debe limitarse a la instrucción", convencido de que, si la escuela pública se dedicase, también, a educar, atacaría "el derecho de los padres" y "llegaría a ser contraria a la independencia de las opiniones» (7, pp. 42-47). Según él, «la libertad de estas opiniones no sería sino ilusoria si la sociedad se apoderase de las generaciones nacientes para dictarles lo que deben hacer. El que al entrar en la sociedad lleva consigo las opiniones que la educación le ha proporcionado, ya no es hombre libre, es esclavo de sus maestros» (7, pp. 46-47).

Por razones muy similares a las de Condorcet, el propio Marx, en la Crítica al Programa de Gotba (27, p. 42) enjuiciaba como "absolutamente inadmisible" una "educa" ción popular a cargo del Estado». Y precisaba:

iUna cosa es determinar, por medio de una ley general, los recursos de las escuelas 
públicas, las condiciones de capacidad del personal docente, las materias de enseñan$z a$, etc., y velar por el cumplimiento de estas prescripciones legales mediante inspectores del Estado (...), y otra cosa, completamente distinta, es nombrar al Estado educador del pueblo! Lejos de esto, lo que hay que hacer es substraer la escuela a toda influencia por parte del gobierno y de la iglesia.

Marx no podía prever, sin duda, la orien. tación que, en el futuro, iba a adquirir la educación marxista-leninista, en los países comunistas, cuando en la exposición realizada en las sesiones de los días 10 y 17 de agosto de 1869 , en el Consejo general de la A.I.T. (29, p. 159) establecía que:

En las escuelas no hay que enseñar más que gramática, ciencias naturales... etc. Las reglas gramaticales no cambian, ya sea un conservador clerical o un librepensador quien las enseñe. Las materias que admiten con. clusiones diversas no tienen por qué ser enseñadas en las escuelas.

También Tolstoi preconizaba abstenerse de educar a los niños en la escuela, persua. dido de que ése era un derecho exclusivo de la familia:

Estoy convencido de que la escuela no debe intervenir en educación, pura incumbencia de la familia; no debe castigar ni recompensar lo que ella no tiene derecho, que su mejor policía y administración con" siste en dejar a los alumnos en absoluta libertad de aprender y de arreglarse entre ellos como mejor les parezca $(46$, p. 24$)$.

Educar suponía para Tolstoi arrogarse el derecho de premiar y castigar, es decir, de ejercer una violencia sobre los escolares que él consideraba injustificada y peligrosa.

\section{Formacion Total}

Frente a las teorias que acabamos de mencionar, partidarias de instruir, pero no de educar, existen aquellas otras que, por el contrario, conciben la relación pedagógica como totalmente educadora. Dicha totalización excluye, recíprocamente, la instrucción.

En este segundo grupo parece también importante subrayar la diferencia entre las opiniones de quienes niegan la posibilidad de instruir, y las de quienes se limitan a negar la conveniencia de la instrucción, admitiendo sólo la necesidad de la formación.

En el primer caso, cabe incluir la teoría pedagógica de C. Rogers, para quien sólo es posible y valiosa la educación, nunca la instrucción: «los resultados de la enseñanza son triviales y perjudiciales» $(40$, p. 125$)$. Según su concepto, únicamente son relevantes aquellos aprendizajes "que tienen influencia significativa para la conducta" $(40$, p. 124$)$. Pero ese tipo de aprendizaje que va orienta. do a modificar la conducta "no puede ser transmitido directamente a otra persona" (40. Ibid.), y sólo da resultado con el autodescubrimiento y la autoasimilación.

Rogers, que parte de una teoría de la incomunicabilidad, tiende a concebir la persona de acuerdo con esquemas monadológicos:

El ser humano tiene la capacidad latente - manifiesta de comprenderse a sí mismo, de resolver sus problemas de modo suficiente para lograx la satisfacción y la eficacia necesarias a un funcionamiento adecuado (...); tiene igualmente tendencia a ejercer esa capacidad (41, vol. I, pp. 28-29).

Al igual que una mónada autoabastecida de sus correspondientes predicados y de la energía interior necesaria para la acción inmanente y el autoconocimiento, el yo, según Rogers, es una totalidad cerrada e incomunicada con los demás yoes, excepto por la vía de la empatía, de la representación interior del otro. Para que esa comunicación empática sea posible, debe existir previamente una armonía efectiva, un clima de confianza mutua:

El ejercicio de esa capacidad requiere un contexto de relaciones humanas positivas, favorables a la conservación y a la valorización del yo, es decir, requiere relaciones carentes de amenaza o de desafío a la concepción que el sujeto se hace de sí mismo $(41, p p .28 \cdot 29)$. 
De acuerdo con estos principios, la instrucción no es posible, puesto que nadie puede enseñar nada importante o valioso a ningún otro (Cfr. 40, pp. 124-125). Cada hombre sólo puede aprender por sí mismo, de un modo inmanente, y exclusivamente aquellos contenidos que no son amenazadores para el yo (40, p. 127). El influjo educador cabe, sin embargo, por vía indirecta: mediante la creación de un clima de confianza y de relaciones humanas positivas, favorables a la valorización del yo.

Algo distinta y acaso menos radical que la de Rogers es la posición de Neill, quien no niega la posibilidad de la instrucción, pero la considera contraproducente y dañina. En su opinión:

"las materias escolares son uno de los medios empleados por el gobierno para evitar que el niño reciba educación” (30, p. 43).

Partidario de preocuparse únicamente de las emociones, excluyendo la formación de la inteligencia (Cfr. 32, p. 352), insiste constantemente en que "la educación debería relacionarse con la vida y no con la adquisición de conocimientos» $(32$, p. 353$)$. Hay que formar "corazones, no sólo cabezas en la escuela», como reza el título de uno de sus libros (31). Porque, después de todo, «la mayor parte de lo que el niño aprende en la escuela lo olvida casi inmediatamente (...) Alguien dirá que nos enseñaron a pensar. iTonterías! Nos enseñaron a aburrirnos. La enseñanza en sí tiene poca importancia en un mundo enfermo" $(32$, p. 352$)$.

Neill es, después de todo, un heredero de Rousseau, que también concedía, como es sabido, mucha mayor importancia a la educación de las emociones y a las leyes del corazón que a la vana erudición de los sabios (Cfr. 42, p. 109).

\section{Educación Integral}

La relación pedagógica puede ser concebida, sin embargo, de acuerdo con un tercer tipo de totalización, que no excluye la formación, ni tampoco la instrucción, sino que fusiona a ambas. Ello conduce a un concepto de educación integral que es solidaria y complementaria de la idea de Educando Total. El ideario comeniano de una docencia que sintetiza erudición, virtud y piedad, o la educación preconizada por Marx, combinando trabajo productivo con enseñanza y gimnasia, constituyen dos buenos ejemplos de esta idea.

En La instrucción integral, Bakunin (2) propone objetivos similares y abarca, "al lado de la "enseñanza científica o teórica" (...) la "enseñanza industrial o práctica". Sólo así se forma el hombre completo" (2, p. 49). Aunque Bakunin exige, además, una educación moral en y para la libertad (2, p. 50).

\section{Límites de la relación pedagógica concebida como Relación Total}

Dichos límites vienen dados, obviamente, por el hecho de que ni la instrucción ni la formación pueden ofrecerse nunca en estado puro, pues no resulta posible despojar los contenidos instructivos de sus consecuencias educativas; pero tampoco cabe realizar una educación del carácter ajena a alguna forma de instrucción o de información. De ahí la paradójica posición que desempeña Sócrates en el Protágoras platónico, tratando de negar la posibilidad de enseñar la virtud, precisamente él, el educador por antonomasia de los atenienses, él, que había intentado repetidamente convencer de que la virtud era una consecuencia de la sabiduría y del recto conocimiento. En esta paradoja han incurrido, asimismo, aquellos educadores que han propiciado una instrucción sin eđucación. ¿Es posible enseñar, como quería Tolstoi, sin premios ni castigos? ¿Acaso el propio éxito o fracaso en la instrucción no comporta lo que el conductismo llama "refuerzos" positivos y aversivos? $\mathrm{Y}$ con más razón todavía en cuanto que la escuela de Yasnaia Poliana impartía notas y calificaciones que, según Tolstoi, habían establecido los propios alumnos, "porque en ellas encuentran una apreciación de su trabajo" (46, p. 28). Además, pretender ensenar - como Tolstoi- Historia Sagrada, His- 
toria Rusa o Geografía, sin proporcionar, simultáneamente, una formación religiosa y política es, en realidad, una quimera.

De igual modo, resulta también inconsistente la exigencia de una educación sin instrucción. El educador que no quiere instruir instruye al menos sobre un tipo de contenidos: sobre su propia doctrina, que se convertirá, de forma abusiva, por unilateral, en materia privilegiada de la información o ins" trucción impartida al discípulo. Por ello la educación sin instrucción - la de Rogers, la de Neill, etc.- constituye, en el fondo, una impostura.

Pero si instrucción y formación no pueden subsistir por separado, ya que se incluyen y exigen mutuamente, la conjunción de ambas en un proyecto totalizador de educación conduce a una idea igualmente metafísica: es la idea de Educación Integral, íntimamente emparentada con la idea de Hom. bre Total, y cuyas dificultades internas ya fueron examinadas anteriormente, al mostrax cómo cualquier determinación de esa idea implicaba su limitación y, por tanto, su disolución como idea totalizadora.

Hemos examinado un conjunto de plasmaciones de esas tres grandes ideas que la razón pedagógica elabora cuando totaliza cada una de las tres condiciones de la experiencia educativa, y hemos podido ver hasta qué punto dichas ideas conducen siempre a contradicciones inevitables.

De todo ello puede inferirse que el com. portamiento de las grandes ideas pedagógicas es, por lo menos, análogo al de las grandes ideas metafísicas, tal y como Kant lo analizó, y que la razón pedagógica, siendo un caso particular de la razón práctica, es, también, generadora de ilusiones y víctima del error transcendental, a causa de la inevitable inconsistencia en la que incurren sus genuinas construcciones.

Sin embargo, el propio Kant advirtió, en el Apéndice de la Dialéctica Trascendental, que las ideas de la razón, en tanto que necesarias e ineludibles, habian de tener alguna función y un uso que no fuera abusivo ni contradictorio, "puesto que nos son indicadas por la naturaleza de nuestra razón, y es imposible que ese tribunal supremo de todos los derechos y pretensiones de nuestra especula. ción contenga ya originarias ilusiones y engaños" (20, vol. II, p. 296).

A partir de esta suposición, Kant creía poder distinguir un uso puramente «regulativo" de la razón, que contrastaría con su uso "constitutivo". Éste tenía una función ostensiva, reificadora, constructiva: trataba de determinar los "objetos» de las ideas, incurriendo necesariamente en contradicción. En cambio, el uso "regulativo" era puramente heurístico y hacía, de esas ideas, simples "objetivos" que, a modo de máximas, indicarían la dirección en la que habría que buscar los objetos, pero sin determinar nunca los objetos mismos.

Kant observaba, asimismo, que las tres ideas metafísicas, utilizadas de un modo pu. ramente heurístico o regulativo, fortalecían y favorecían hasta lo infinito el uso empírico de la razón, «abriendo nuevos caminos que el entendimiento no conoce" (20, vol. II, p. 303), y ofreciendo al propio entendimiento la ventaja de una coherencia sistemática que "no solamente favorece la extensión de éste, sino que, al mismo tiempo, garantiza, también, su exactitud» (Ibid.).

Pues bien, las grandes ideas pedagógicas, tomadas como ideas puramente regulativas, desempeñan un cometido análogo, propor" cionando a la práctica educativa un principio de coherencia interna y abriendo para ella la vía de un perfeccionamiento infinito, que salta siempre más allá y sin desalentarse nunca por las limitaciones e imperfecciones de la realidad pedagógica.

Por ello mismo, ninguna doctrina pedagógica que se precie puede renunciar a la aspiración de educar lo más integralmente posible al educando, y a controlar lo mejor y más completamente que pueda, los estímulos que se ejercen sobre él. Hay que tener siempre presente, sin embargo, que cual. quier determinación de estas aspiraciones, en un programa efectivo, va a suponer, necesariamente, la quiebra de estas ideas y una realización contradictoria de las mismas. 
Esto no quiere decir, sin embargo, que las ideas pedagógicas hayan de ser mantenidas en el limbo de la teoría, para que ningún compromiso empírico llegue a manchar su pureza. Conferirles una función regulativa significa, justamente, lo contrario: hacerlas solidarias de la práctica y comprometerlas en una atenta vigilancia que impida cualquier forma de totalitarismo. El pensamiento necesitará siempre aceptar un cierto grado de impureza, de incompletitud, de pluralidad en la experiencia educativa, y necesitará, asimismo, habituarse a coexistir con la imperfección, pues el concepto de una educación perfecta y absoluta conduce, al final, a la más pavorosa quimera concebible.

Obras citadas en el texto

1. ARISTÓteless. Ética a Nicómaco (La Ética de Aris. tóteles), tr. Pedro Simón Abril, Madrid, 1918. Real Academia de Ciencias Motales y políticas.

2. BAKUNIN, M., La Instrucción Integral, to. e introducción C. Lozano, Barcelona, 1979, Calamus

3. BERNFeld, S., Sísifo o los limites de la Educaciōn, tr. C. Ceretti, Buenos Aites, 1975, Siglo XXI.

4. CAPANÄGA, V., «Introducciōn» a La Ciudad de Dios de San Agustín, en Obras de San Agustin, Vol. XVI, Madrid, 1977, B.A.C., Pp. 7-103.

5. Comenio. J.A., Pampaedia, tr. e intr. P. Cammarota, Roma, 1968, Armando Armando Edi. tore.

6. Comen1O. J.A., Didáctica Magna, tr. e. intr. Gabriel de la Mora, México, 1976, Porrua.

7. CONDORCET. Escritos pedagógicos, tr. D. Barnés, Madrid, 1922, Calpe.

8. DILTHEY, W., Fundamentos de un sistema de Pedagogía, tr. L. Luzuriaga, Buenos Aires, 1965 , Losada (6. ed.)

9. ENGELS, F., «Principios del Comunismo. (Proyecto de profesión de fe comunista)». en MARX y ENGELS, Biografia del Manifiesto Comunista, tr. W. Roces, México, 1964, Compañía General de Ediciones.

10. LENIN, V.L., La enfermedad infantil del izquier. dismo en el comunismo, tr. no consta, Madrid, 1975, Ariel.

11. Farrington, B., Ciencia y Política en el Mundo Antiguo, tr. D. Plácido Suátez, Madrid, 1965. Ciencia Nueva.

12. Fichte, J.G., Discursos a la nación alemana, $t$ L. Agosta y M.J. Varela, Madrid, 1977, Editora Nacional.
13. Foucault, M., Vigilar y Castigar, tr. Aurelio Garzón del Camino, Madrid, 1978, Siglo XXI.

14. GANSS.J., Universidady educación jesuiticas, tr. A. Quevedo y B. Blanco, La Habana, 1958, J.P.A.S.I.

15. HEGEL. G.W.F., Lecciones sobre la Historia de la Filosofía (3 vol.), tr. W. Roces, México, 1955 , F.C.E.

16. HEGEL, G.W.F., Filosofia de la Historia, tr. de la edición Brunstäd, J.M. Quintana, Batcelona, 1970 , Zeus.

17. ILliCH. I., La sociedad desescolarizada, tr. G. Espinosa, Barcelona, 1973, Barral.

18. Illich, I., La convivencialidad, tr. M.P. de Gossmann, Barcelona, 1974, Barral.

19. JAEGER, W., Paideia: los ideales de la cultura griega, tr. J. Xirau y W. Roces, México, 1978, F.C.E. $(2$ ed. $)$.

20. KANT, E., Crítica de la Razón Pura, tr. J. del Pe. rojo, Buenos Aires, 1973, Losada (2 vols.).

21. KaNT. E., Crítica de la Razón Práctica, tr. J. Rovira Armengol, Buenos Aires, 1961, Losada.

22. KEMP's, Tomás Hemerken de, Imitación de Gristo, tr. L. E. Sansegundo, Barcelona, 1974, Regina.

23. KRUPSKAIA, N., La educación comunista. Lenin y la juventud, Madrid, 1978, Nuestra Cultura.

24. LoYOLA. San Ignacio de, Obras Completas, transcripción, introducción y notas de I. Iparta. guirre y C. de Dalmases, Madrid, 1977, B.A.C. (3: ed. revisada).

25. MAKARENKO. A.S., Colectividad y Educación, tr. no consta, Madrid, Nuestra Cultura, 1979.

26. MARCUSE, H., 1968, El Hombre Unidimensional, tr. J. García Ponce, México, 1968, J. Mortíz. 
27. MARX, K., Crítica del Programa de Gotba, tr. Instituto del marxismo-leninismo, Madtid, 1971, Ricardo Aguilera.

28. MarX, K., ENGEIS, F., La ideología alemana, tr. W. Roces, Montevideo, 1968, Pueblo Unido.

29. MARX. K., ENGELS. F., Textos sobre educación y enseñanza, Madrid, 1978, Comunicación.

30. NelL, A. S., Maestros problema y los problemas del maestro, tr. C. de Grossi, México, 1975, Editores mexicanos unidos.

31. NeILL, A. S., Corazones, no sólo cabezas en la escuela, tr. C. de Grossi, México, 1975, Editores mexicanos unidos.

32. NeILL. A. S., Autobiografia. Neill! Neill! Orange peel!, tr. Carlos Valdés, México, 1976, F.C.E.

33. Neill, A. S., Summethill, tr. F. Torner, México, 1978, F.C.E.

34. NieTzSCHE, F., El Anticristo, tt. A. Sánchez Pascual, Madrid, 1974, Alianza.

35. PLATŌN, la République (3 vols.), en Oeuvres complètes, vols. VI.VII y VIIl, Patis, 1965-67, Les Belles Letres.

36. Platön, Protágoras, tr. J. Velarde. Prólogo: G. Bueno, Oviedo, 1980, Pentalfa.

37. POPPER, K. R., La Sociedad abierta y sus enemigos, tr. E. Loedel, Barcelona, 1981, Paidós.

38. REIMER, E., La Escuela ha muerto, tr. E. Mayans, Batcelona, 1976, Barral.
39. RiVAdENEYRA. P. de, Vida de Ignacio de Loyola, Madrid, 1946, Espasa Calpe (3. ed.).

40. ROGERS, C. R., Libertad y Creatividad en la Educaciōn, tr. Silvia Vetrano, Buenos Aires, 1975 , Paidós.

41. ROgers, C. R. y KingeT, G. M., Psicoterapia y relaciones bumanas, Madrid, 1971. Alfaguara ( 2 vols.).

42. Rousseau. J. J., Emile où de l'éducation, París, 1961, Garnier.

43. SANTONI, A., Historia social de la educación, tr. M. Solivella, Batcelona, 1981, Reforma de la Es. cuela.

44. SCHELER, Max, La Idea del Hombre y la Historia, tr. J. J. Olivera, Buenos Aires, 1980, La Pléyade.

45. SNYDERS. G., La pédagogie en France aux XVIiè et XVIII $\dot{e}$ siècies, Paris, 1965 , P.U.F.

46. TOLSTOI, L., La Escuela de Yasnaia Poliana, tr. Gómez Pinilla, Madrid, 1977, Júcas.

47. VOLTAIRE, Diccionario filosófico (3 vols.), tr. no consta, Buenos Aires, 1960, Sophos.

48. WHITEHEAD. A. N., Los fines de la educación, tr. D. Iuminski, Buenos Aires, 1965, Paidós (3. ed.). 